\title{
The Source of Arsenic and Nitrate in Borrego Valley Groundwater Aquifer
}

\author{
Mohammad Hassan Rezaie-Boroon*, Jessica Chaney, Bradley Bowers \\ California State University, Los Angeles, Geosciences and Environment Department, Los Angeles, USA \\ Email: "mrezaie@calstatela.edu
}

Received 12 September 2014; revised 8 October 2014; accepted 2 November 2014

Copyright (C) 2014 by authors and Scientific Research Publishing Inc.

This work is licensed under the Creative Commons Attribution International License (CC BY).

http://creativecommons.org/licenses/by/4.0/

(c) (i) Open Access

\section{Abstract}

Groundwater in California is very precious, yet what we can withdraw is often contaminated with natural and anthropogenic pollution sources. We have examined the Borrego Valley (BV) groundwater ( $N=6$ wells) in southern California to understand the source of arsenic and nitrate in some of its groundwater production wells. The results show that the arsenic values range from $<2 \mathrm{ppb}$ to $12.2 \mathrm{ppb}$ and the nitrate values from $<1 \mathrm{ppm}$ to $10.2 \mathrm{ppm}$ for different wells respectively. The results showed that the arsenic concentration increased $270 \%$ for the well \# ID1-10 since 2004 and showed an increase of $63 \%$ since 2013 respectively. For other wells the results showed an increase of $147 \%$ and $72 \%$ since 2001 . The nitrate concentration has jumped $42 \%$ in concentration since last year in one of the wells. The objective of this study is to understand the nature and source of arsenic and nitrate in BV groundwater aquifer as to how this change in arsenic and nitrate concentration occurs through the time. The arsenic retention in the sediments is highly variable and controlled by local processes as a result of natural weathering process of metamorphic bedrock. The second results from the development of strongly reducing conditions at near-neutral pH values, leading to the desorption of arsenic from mineral oxides and to the reductive dissolution of Fe and Mn oxides, also leading to arsenic release. The high arsenic concentrations in some groundwater wells in Borrego Valley CA require the need for reconnaissance surveys in mineralized areas of fractured crystalline basement. Net groundwater extraction values are based on an irrigation efficiency of 78 percent with 14 to 22 percent irrigation return. We believe that the return flow from irrigational activity could be one of the major sources of nitrate transferring the agricultural contaminants such as nitrate to Borrego Valley aquifer.

\section{Keywords}

Hydrogeology, Hydrogeochemistry, Groundwater, Borrego Valley, Return Flow

\footnotetext{
"Corresponding author.
} 


\section{Introduction}

Groundwater is a major source of public drinking-water supply for many of the cities located in the Colorado Desert hydrogeologic province of California [1]. While drought and water shortage have become an increasingly serious problem in California especially in arid semi arid regions, over pumping of the aquifer has resulted in depletion of the volume of groundwater in storage within the aquifer system and a decline of groundwater levels in Borrego Valley (BV) California [2]. Equally important is the water quality to human health, which gains a great deal of interest with increasing demand for drinking water. Past research studies show higher concentrations of arsenic and nitrate is found in the ground water aquifer within fractured crystalline bedrock in BV [3]. Additional studies show that health risk based on the presence of arsenic in the groundwater does not exclusively occur in southern California but in the western United States [4]. In terms of nitrate concentration, the nitrate values in the BV study area groundwater wells were less than the health-based benchmark values $(10 \mathrm{mg} / \mathrm{l})$, but the results indicate the fluctuations of nitrate values possibly depending on the oxidation-reduction state of the groundwater [5].

High concentrations of nitrate can adversely affect human health, particularly the health of infants. Thus, the understanding of groundwater chemistry, occurrence and distribution of chemical constituents in groundwater are valuable for identifying the natural and human factors affecting water quality [6]. The controlled processes on chemical composition of groundwater include evaporation, dissolution/precipitation, weathering of silicates, oxidation-reduction, sorption and exchange reactions, transformation of organic matter, and mixing processes [7]. Similarly, research studies indicate that the mobilization of arsenic and nitrate in sedimentary aquifers of these regions may be, in part, a result of changes in the geochemical environment due to agricultural irrigation [8]. Prior to the current study, the groundwater quality in the BV region was investigated by the US Geological Survey (USGS) from December 2008 to March 2010 and by Borrego Valley Water District (BVD) in the last 10 years.

Generally, all studies dealing with arsenic are in good agreement that the arsenic originates either from natural sources (geogenic) or industrial activities and/or fertilizer runoff (anthropogenic). Nevertheless, the processes leading to the release of arsenic in groundwater aquifer are not yet fully understood. The literature synthesis indicates various hypothesis concerning the release of arsenic 1) by oxidation of arsenic-bearing pyrite [9]-[11], 2) by competitive exchange of phosphate from fertilizers [12] and 3) by reduction of iron hydroxides under anoxic conditions [13] [14]. Our study, however, provides a baseline of groundwater quality in BV using the current ongoing research results and literature synthesis addressing the source and origin, trend, and pattern of contamination in BV aquifer. Furthermore, it is important to identify the enduring processes in the environment for the nitrate and arsenic concentration values in BV groundwater and to recognize the cause for fluctuation of this value through the time. Therefore, the main objective of this study is to find the exact source and the pattern of arsenic and nitrate in BV aquifer. Furthermore, the purpose of this research study is to examine the ground-water chemistry in a groundwater basin, which historically contains high arsenic concentrations. And also, it is important to identify geochemical patterns that would help explain the occurrence of high arsenic concentrations. We believe that the distribution of arsenic in the BV aquifer depends on the partitioning between the aqueous and solid phase. Therefore processes causing changes in the aquifer geochemistry need to be considered since they directly affect the mobility of arsenic.

\section{Materials and Methods}

\subsection{Study Area}

The Borrego Valley (BV) is a desert area with surface area of approximately $616 \mathrm{~km}^{2}\left(\sim 238 \mathrm{mi}^{2}\right)$. BV is located in southern California (in the northeastern portion of San Diego County), within the Colorado Desert geomorphic province, (in the westernmost part of the Sonoran Desert), approximately $137 \mathrm{~km}$ (85 miles) northeast of San Diego (Figure 1). BV has an arid climate with an average annual precipitation ranging from 76 to $152 \mathrm{~mm}$ (3 to 6 inches). Most of the precipitation occurs during the winter months, between November and April [2].

\subsection{Geological and Hydrogeological Setting}

\subsubsection{Topography}

$\mathrm{BV}$ is bounded on the north and northeast by Coyote Mountain, on the west and southwest by the San Ysidro 


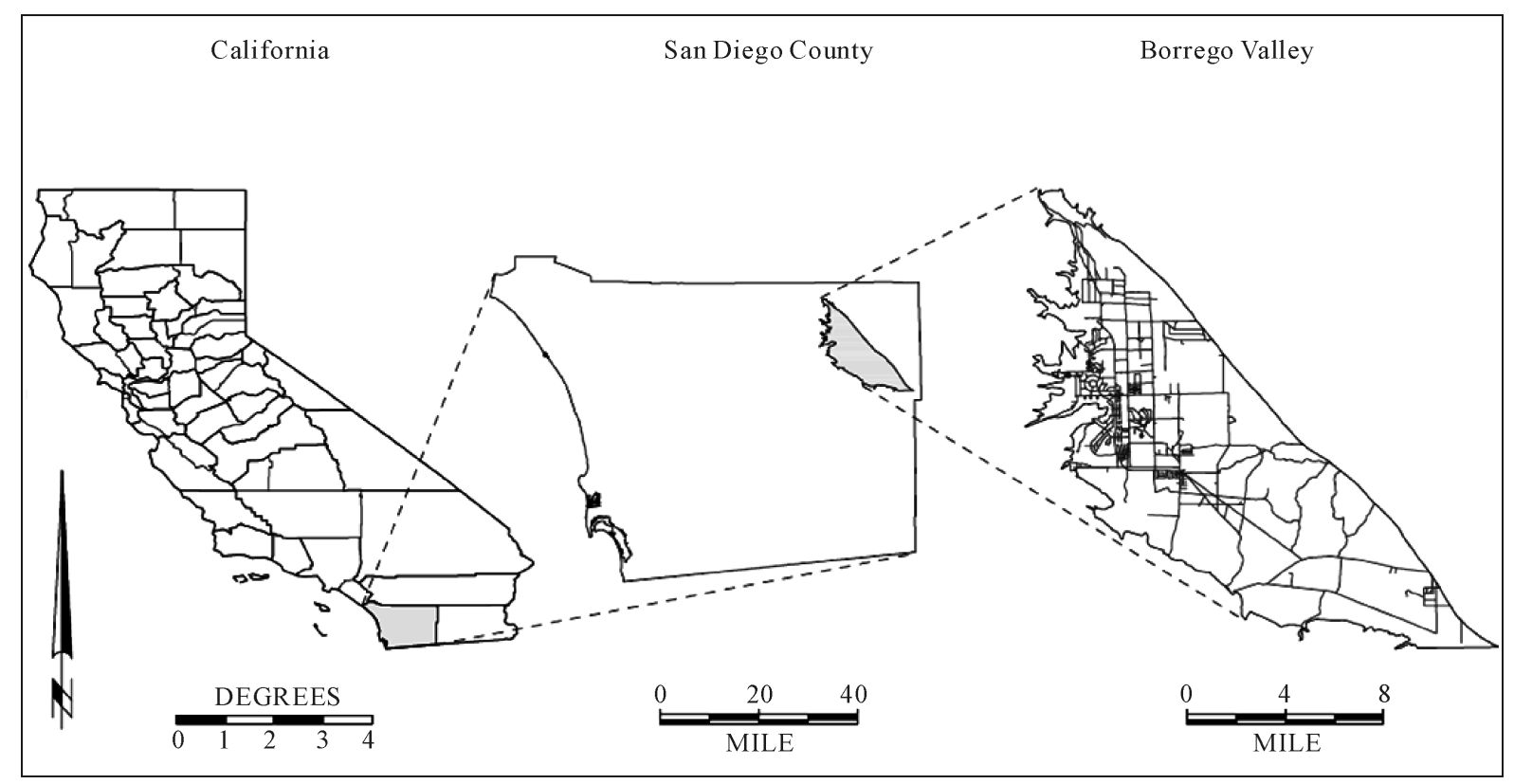

Figure 1. Regional location map of Borrego Valley, CA (modified after [2]).

Mountains and Pinyon Ridge, and on the south by the Vallecitos Mountains (Figure 2). The east side of BV is bordered by the Coyote Creek fault, with the Borrego Badlands beyond, and Borrego Mountain. The primary sources of recharge to the BV groundwater basin are the multiple creeks and intermittent streams that drain to BV from the surrounding mountainous areas, comprising more than $1036 \mathrm{~km}^{2}$ (400 square miles) of watershed $[2])$.

The $285 \mathrm{~km}^{2}$ (110 square mile) valley floor ranges in elevation from $365.76 \mathrm{~m}$ (1200 feet) at the northern end of the valley, in the vicinity of Ocotillo Flat near Coyote Canyon, to approximately $140 \mathrm{~m}$ (460 feet) in the vicinity of Borrego Sink. The elevation of the valley floor generally ranges from about 243.80 to $304.8 \mathrm{~m}$ (800 to 1000 feet) around the margins of the basin, and declines towards the center of the valley to Borrego Sink. The surrounding mountains are characterized by steep slopes with elevations ranging from 243.80 to $304.8 \mathrm{~m}$ (800 to 1000 feet), where the mountain slopes reach the valley floor, to mountain peaks ranging in elevation from approximately 518.16 m (1700 feet) at Yaqui Ridge (southeast extension of Pinyon Ridge) to over 6500 feet at Hot Springs Mountain (in the San Ysidro Mountains). Figure 2 characterized region with surrounding mountains and groundwater level elevation.

\subsubsection{Hydrology, Geology, and Hydrogeologic Setting}

The geology, hydrogeology and water resources of BV have been studied and reported by various authors since the early 1900's. In regards to water resource issues in the BV, there are three features to be considered 1) the watershed or drainage basin that includes the surrounding mountains from which runoff from rainfall in the mountains is drained into the valley and recharges the aquifer via canyons and other creeks. Coyote Canyon, at the northwest end of the valley, is the most significant drainage feature, 2) the valley floor, which is bounded and defined by mountains and canyons on the north, west and by the Borrego Badlands to the east and 3) the groundwater basin, which underlies the valley floor [15].

The BV located within the BV groundwater basin (12,000 AFY), encompasses a large section of the AnzaBorrego Desert State Park The groundwater basin is identified by DWR as groundwater basin number 7 - 24 with a surface area of about 150,000 acres and includes both the main Borrego and Lower BV area [16].

The BV Basin is filled with up to 2400 feet of poorly consolidated to unconsolidated sediments resting on the basement granite. The USGS Report 82 - 855 identified an upper, middle and lower aquifer [17]. The alluvial sediments filling the basin originated from the weathering action of the rocks in the surrounding mountains. The base of the groundwater basin is a complex of the oldest geologic units in the vicinity of BV and is comprised of the Cretaceous granitic and the Triassic or older meta-sedimentary rocks of the Southern California batholith. 


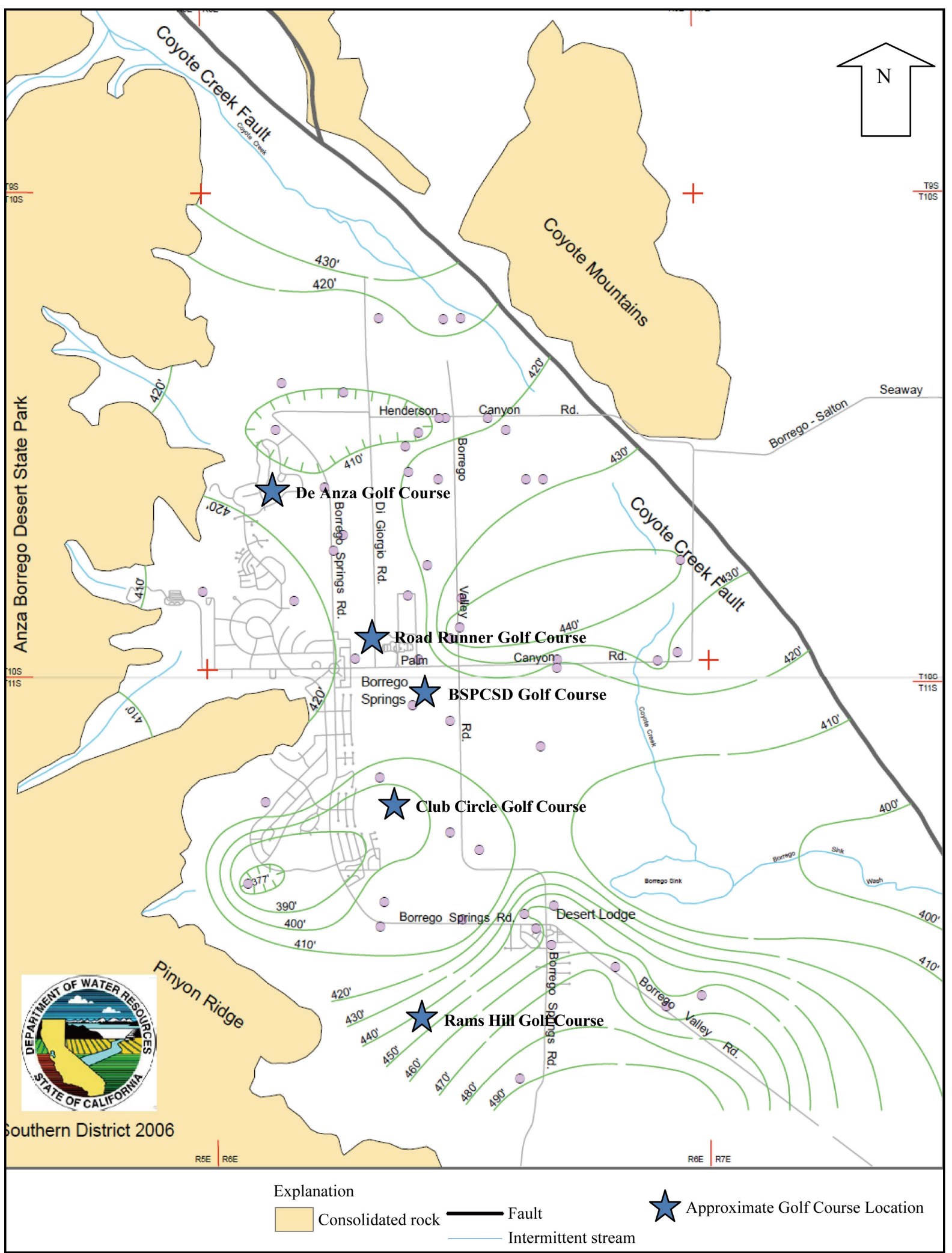

Figure 2. Base map modified from USGS 7.5 minute topographic maps. Groundwater contours area generalized representation of the regional static water level interpreted from 35 wells measured in Spring 2005. Water levels are interpreted to represent unconfined conditions [2] [16] (Courtesy of DWR, 2005; Netto, 2001). 
The basement complex is the ultimate base of the aquifer system and crops out on the north, west and south of the basin as well as at Borrego Mountain [2]. The upper aquifer is comprised of Holocene to Pleistocene age alluvial fan, playa and eolian deposits. The unit is about 1000 feet in thickness at the north end of the basin. Specific yields for these deposits range from 15 to 25 percent [16]. This aquifer is the principal source of groundwater in BV and well yields are about $2000 \mathrm{gal} / \mathrm{min}$ [18]. The middle aquifer is of Pleistocene age and composed of continental deposits, including moderately consolidated sand, gravel, and boulders. Thickness ranges to 700 feet in the middle aquifer and is thickest near the center of the valley, but thins towards the southeast [18]. Specific yield ranges from 5 to 10 percent in the middle aquifer [16]. Groundwater is easily extracted from this aquifer. The lower aquifer is also of Pleistocene age and consists of continental deposits, including moderately consolidated sand, gravel, and boulders. According to DWR (1984) the lower aquifer reaches 1800 feet in thickness in the south-central part of the valley. Specific yield ranges from 1 to 5 percent in the lower aquifer [16].

\subsection{Sampling Preparation and Sampling Well Locations}

A total of six groundwater production well were sampled in the study area. Groundwater sampling was conducted according to standard procedures [19] [20] in June 2014 in BV. The production wells were chosen specifically based on the history of contamination records for arsenic and nitrate for each well. The sampling wells include ID1-10, ID1-12, ID4-10, ID4-11, ID4-18, and Wilcox, which were located in the western edge of BV (Table 1 and Figure 3).

In the field, before sampling groundwater wells, each well was pumped continuously to purge at least three casing-volumes of water from the well and also until $\mathrm{pH}$ and temperature readings stabilized [21]. A total of 12 groundwater samples including blank and replicates samples were collected and sent to the lab for arsenic and nitrate analysis using brand new sample containers (Teflon ${ }^{\circledR}$ bottles). The containers were clearly labeled with well identification number, date of collection, type of parameter to be analyzed, the preservative type used, whether they were field filtered using $0.45 \mu \mathrm{m}$ cellulose filters or field unfiltered. The water samples were acidified with $0.7 \mathrm{~N} \mathrm{HNO}_{3}(\mathrm{pH}=2)$ for the arsenic analysis. For the quality assurance (QA) and quality control (QC) purposes, we used duplicates, blank samples, and standard reference materials according to EPA standards. Field blank and duplicate samples were collected on site to evaluate positive bias as a result of contamination

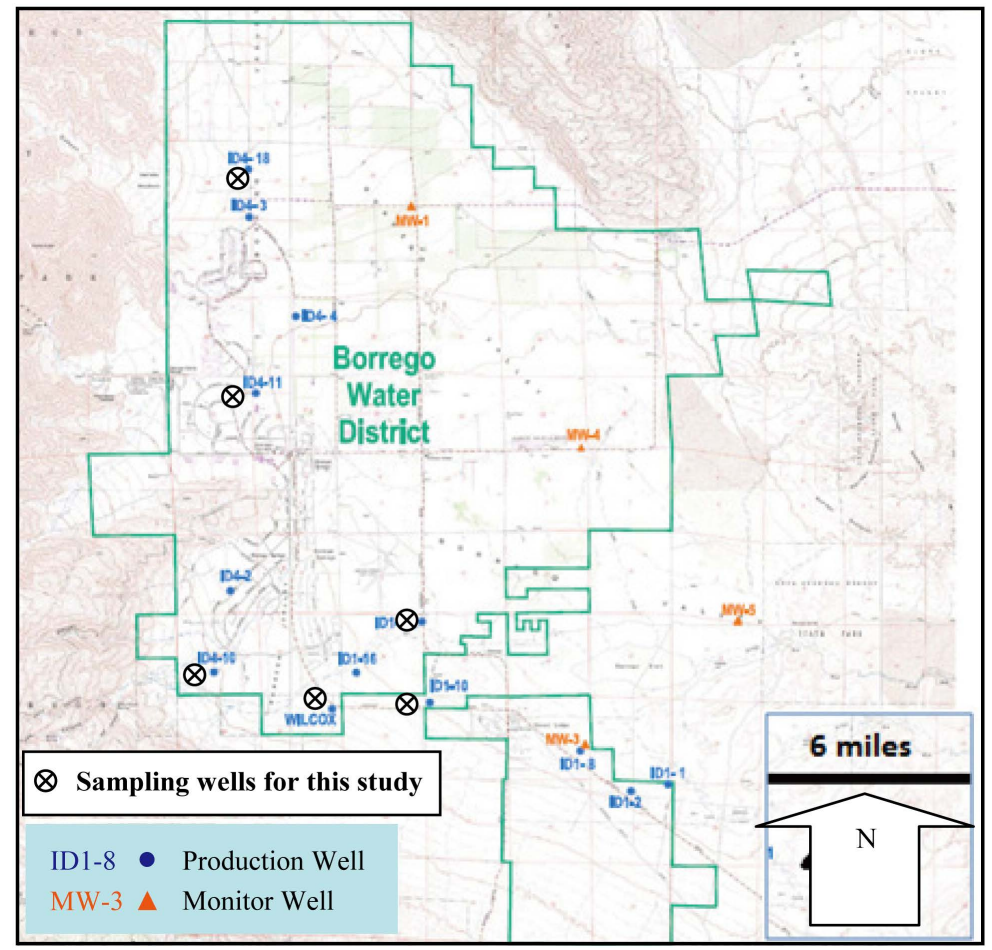

Figure 3. Sampling locations (modified after [15]). 
Table 1. List of sampled production wells in BV with well characteristics. N/A means here as the data "not available". The supply wells data is the courtesy of BWD (Source: BWD, 2014). N/A: not available.

\begin{tabular}{|c|c|c|c|c|c|c|c|c|c|c|c|c|}
\hline \multirow[b]{2}{*}{ Well ID } & \multirow[b]{2}{*}{ Latitude } & \multirow[b]{2}{*}{ Longitude } & \multirow{2}{*}{$\begin{array}{c}\text { Land } \\
\text { surface } \\
\text { elevation } \\
\text { (ft) }\end{array}$} & \multicolumn{9}{|c|}{ Well data } \\
\hline & & & & $\begin{array}{c}\text { Total } \\
\text { depth } \\
(\mathrm{ft})\end{array}$ & $\underset{(m V)^{* *}}{\text { Eh }}$ & $\mathrm{pH}^{* *}$ & $\begin{array}{l}\text { Completed } \\
\text { depth }^{*}(\mathrm{ft})\end{array}$ & $\begin{array}{c}\text { Water } \\
\text { level }^{*} \\
(\mathrm{ft})\end{array}$ & $\begin{array}{l}\text { Diameter } \\
\text { (in) }\end{array}$ & $\begin{array}{l}\text { Well } \\
\text { yield } \\
\text { GPM }\end{array}$ & $\begin{array}{l}\text { Well } \\
\text { yield } \\
\text { GPM }^{* *}\end{array}$ & $\begin{array}{c}\text { Total } \\
\text { perforated } \\
(\mathrm{ft})\end{array}$ \\
\hline ID4-18 & 33.306749390 & -116.384712840 & 691.06 & N/A & -25.27 & 6.97 & 570 & 301.2 & 12 & 250 & 170 & N/A \\
\hline ID4-11 & 33.267497550 & -116.383355020 & 614.06 & 800 & 23.5 & 6.91 & 770 & 216.6 & 14 & 900 & 900 & 310 \\
\hline ID1-12 & 33.226028270 & -116.348315130 & 532.24 & 768 & -45.77 & 7.37 & 580 & 143.2 & 14 & 900 & 950 & 320 \\
\hline ID4-10 & 33.218318120 & -116.392224090 & 830.29 & 630 & 35.3 & 7.17 & 630 & 451 & 8 & 100 & 100 & 210 \\
\hline ID1-10 & 33.211789010 & -116.346811970 & 594.74 & 816 & -71.8 & 7.65 & 392 & 236.1 & 12 & 350 & 350 & 210 \\
\hline Wilcox & N/A & N/A & N/A & N/A & -61.7 & 7.49 & N/A & 304.2 & N/A & 150 & 170 & N/A \\
\hline
\end{tabular}

"Data was collected on Oct. 2013 by BWD. ${ }^{* *}$ Observed on the sampling day.

during sample handling or analysis as well as for the inconsistency in results. Physiochemical analysis such as salinity, $\mathrm{pH}$, Eh, and temperature were determined on site using portable pH-meter (Accumet-AP71) and YSI (550A).

All instruments were calibrated (2-point calibration) just before sampling trip using calibration standard solution (Fisher Scientific) three times. Arsenic was measured with inductively coupled plasma and mass spectrometry (ICP-MS/Perkin Elmer; NexION ${ }^{\circledR} 350$ ) and nitrate was analyzed using ion chromatography (Dionex Ion Chromatography ICS-3000) at Associates Labs in Orange County, California using EPA standard methods (for arsenic EPA 200.8 \& EPA 3010A, and for nitrate EPA 300.0). We noted well yield, duration of pumping prior to sampling, depth, pump data, water use, and possible contaminants near the well on water sampling protocol sheets.

In addition, we obtained from Borrego Water District (BWD) office all GPS coordinates for the precise well locations, renewed well completion data, and history.

Upon completion of the sampling trip, the recorded data was updated in the BV groundwater database. The Table 1 shows all well GPS coordinates and their related information such as elevation, depth, Eh, pH values.

\subsection{Quality Assurance and Quality Control Methods}

The purpose of QA is to identify which data best represent environmental conditions and which may have been affected by contamination or bias during sample collection, processing, storage, transportation, and (or) laboratory analysis. 1) Field blank samples were collected to assess contamination during sample handling or analysis, 2) replicate samples were collected to assess variability, 3) matrix-spike tests were done in lab to assess to assess bias of laboratory analytical methods.

The primary purpose of collecting blanks is to evaluate the magnitude of potential contamination of samples with compounds of interest during sample collection, processing, transport, and (or) analysis.

Replicate samples were collected to assess the precision of the water-quality data. Estimates of data precision are needed to assess whether differences between concentrations in samples are because of differences in groundwater quality or because of variability that may result from collecting, processing, and analyzing the samples.

Addition of a known concentration of a constituent (spike) to a replicate sample enables the analyzing laboratory to determine the effect of the matrix, in this case groundwater, on the analytical technique used to measure the constituent. The known compounds added in matrix spikes are the same as those being analyzed in the method. This enables an analysis of matrix interferences on a compound-by-compound basis. For this study, matrix spikes were added by the laboratory performing the analysis.

\section{Results}

The results in this paper are based on our current ongoing investigation of BV aquifers and from the existing 
records. We have examined the BV groundwater ( $\mathrm{N}=6$ wells) in southern California to understand the source of arsenic and nitrate in some of its aquifers. The results show the arsenic values range from $<2 \mathrm{ppb}$ to $12.2 \mathrm{ppb}$ and the nitrate values from $<1 \mathrm{ppm}$ to $10.2 \mathrm{ppm}$ for different wells respectively. The preliminary investigation shows that the arsenic and nitrate concentration has been fluctuating through the time however, the numbers for some wells are much higher than the existing record was published in the last 10 years. The results showed the BV supply well such as ID1-10 had 270\% increase in arsenic concentration since 2004 and 63\% since 2013.

Moreover, some showed $147 \%$ and $72 \%$ increase in arsenic since 2001. According to the BWD (Borrego Water District) the results for this well and Wilcox show a steadily increase in concentration since 2004 (Figure 4). The nitrate concentration has jumped $42 \%$ in concentration since last year in one of the wells. The concentration of nitrate and arsenic varies from well to well; however for some slightly above EPA State MCL (10 ppb for arsenic and $10 \mathrm{ppm}$ for nitrate) (Figure 4). The nitrate values for all sampling wells were lower than MCL of drinking water and human health risk standard/and public health regulation $(45 \mathrm{mg} / \mathrm{l}$ according to $22 \mathrm{CCR}$ §63341). Total dissolved solids (TDS) and arsenic samples were taken every three years as per Department of Public Health Regulations and nitrates samples were taken annually. The arsenic results for 2014 (dry season) showed the well number ID4-10 with lowest concentration ( $<2 \mathrm{ppb})$ and well number ID1-10 with highest concentration (12.2 ppb) respectively. The concentration ranking (ppb) was ID1-10 > Wilcox > ID1-12 > ID4-11 > ID4-10. The nitrate results showed that the well number ID4-10 has the highest concentration (10.2 ppm) and ID4-18 the lowest concentration (2.47 ppm). The concentration ranking according to our study include ID4-10 > ID1-11 > ID4-18. The ranking of nitrate mean $(n=6)$ concentration $(\mathrm{ppm})$ values \pm SD for all previous annual records for nitrate from 2006 and 2014 showed the following ranking: $2012(5.5 \pm 3)>2013(5.3 \pm 3.2)>2014$ $(5.1 \pm 4.4)>2007$ (4.8 \pm 3.3$)$, $2006(4.7 \pm 3.7)>2010$ ( $4.0 \pm 3.4)$ and >2011 (4.1 \pm 2.8$)$. This record obviously shows a fluctuation pattern within 8 years of monitoring. For arsenic the records showed different pattern, a constantly and continuously increasing values in the last 10 years. The ranking of arsenic mean $(n=3)$ concentration (ppb) values \pm SD for all previous records every three year for a 10-year period from 2004 to 2014 showed the following ranking: $2014(6.3 \pm 3.9)>2013(4.9 \pm 2.3)>2010(4.4 \pm 3.8)>2007(3.4 \pm 3.1)>2004$ (3.0 \pm 0.7 ) (Table 2).

The results for all other wells form GAMA website was also investigated to compare them with our results and to understand the trend. GeoTracker GAMA integrates and geographically displays water quality data from multiple sources. Through the GeoTracker website all arsenic, nitrate, and TDS values for the BV groundwater basin 7 - 24 were evaluated and analyzed statistically. The mean concentration for all of the wells in BV water using supply and DWR wells was considered [16].

The GAMA values for arsenic and nitrate were all lower than health-based benchmark (10 ppb for arsenic and $10 \mathrm{ppm}$ for nitrate respectively). The GAMA arsenic concentration (ppb) data showed mean values for arsenic 3.93 for $2013(n=8), 3.45$ for $2010(n=10)$ and 2.34 for $2007(n=14)$. The trend for these values were positive showing an increase in nitrate values through the time despite the fact that these values were all below MCL. The nitrate values showed that the annual rate of concentration from 2006 to 2014 changing through the time.
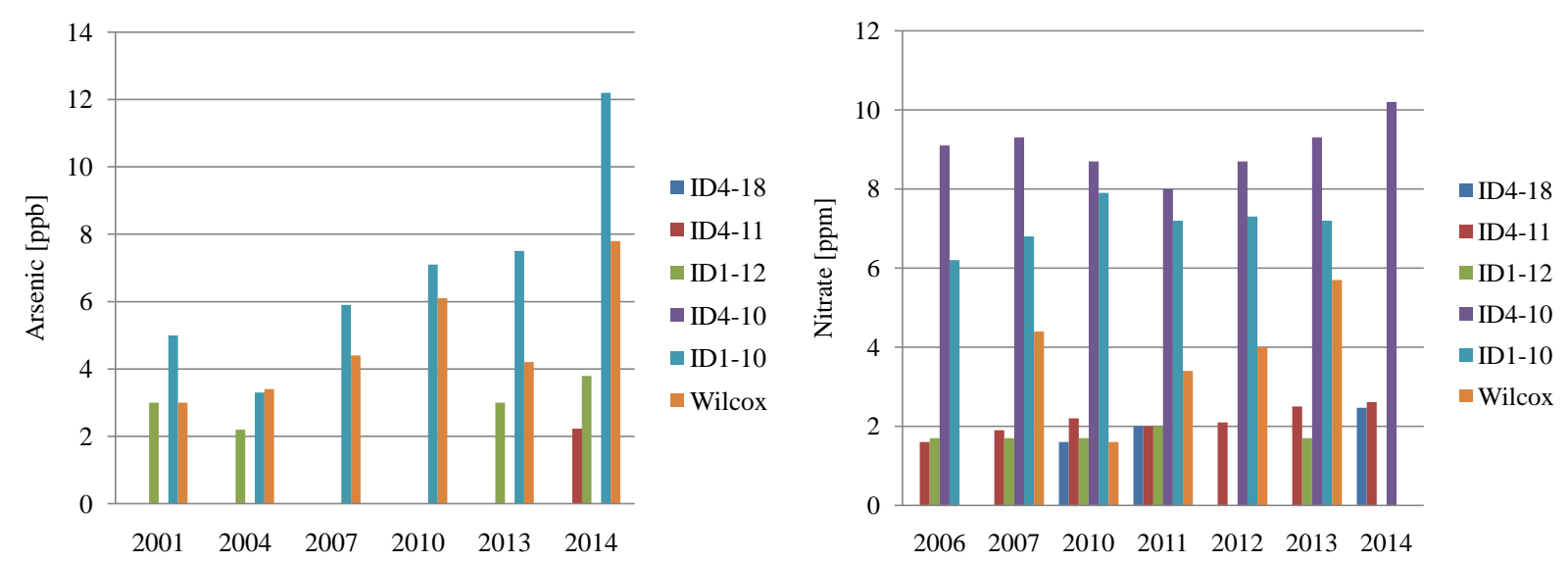

Figure 4. The concentration for arsenic (left) and nitrate (right) for different wells samples in June 2014. The values for 2006 to 2013 is the courtesy of BWD. 
Table 2. The arsenic, nitrate, and TDS concentration for different years and from different wells based on authors results (2014) and data from BWD. N/A = not available.

\begin{tabular}{|c|c|c|c|c|c|c|c|c|c|c|}
\hline \multicolumn{11}{|c|}{ Nitrate [ppm] } \\
\hline & ID4-18 & ID4-11 & ID1-12 & ID4-10 & ID1-10 & Wilcox & Mean & SD & Min & Max \\
\hline 2006 & $<1.0$ & 1.6 & 1.7 & 9.1 & 6.2 & $<1.0$ & 4.7 & 3.7 & 1.6 & 9.1 \\
\hline 2007 & N/A & 1.9 & 1.7 & 9.3 & 6.8 & 4.4 & 4.8 & 3.3 & 1.7 & 9.3 \\
\hline 2010 & 1.6 & 2.2 & 1.7 & 8.7 & 7.9 & 1.6 & 4.0 & 3.4 & 1.6 & 8.7 \\
\hline 2011 & 2 & 2 & 2 & 8 & 7.2 & 3.4 & 4.1 & 2.8 & 2.0 & 8.0 \\
\hline 2012 & $<2$ & 2.1 & $<1.7$ & 8.7 & 7.3 & 4 & 5.5 & 3.0 & 2.1 & 8.7 \\
\hline 2013 & $<2$ & 2.5 & 1.7 & 9.3 & 7.2 & 5.7 & 5.3 & 3.2 & 1.7 & 9.3 \\
\hline 2014 & 2.47 & 2.61 & N/A & 10.2 & NA & NA & 5.1 & 4.4 & 2.5 & 10.2 \\
\hline \multicolumn{11}{|c|}{ Arsenic [ppb] } \\
\hline 2001 & N/A & N/A & 3 & N/A & 5 & 3 & 3.7 & 1.2 & 3.0 & 5.0 \\
\hline 2004 & N/A & N/A & 2.2 & N/A & 3.3 & 3.4 & 3.0 & 0.7 & 2.2 & 3.4 \\
\hline 2007 & N/A & N/A & 0 & N/A & 5.9 & 4.4 & 3.4 & 3.1 & 0.0 & 5.9 \\
\hline 2010 & N/A & N/A & 0 & N/A & 7.1 & 6.1 & 4.4 & 3.8 & 0.0 & 7.1 \\
\hline 2013 & N/A & N/A & 3 & N/A & 7.5 & 4.2 & 4.9 & 2.3 & 3.0 & 7.5 \\
\hline 2014 & N/A & 2.23 & 3.79 & N/A & 12.2 & 7.8 & 6.3 & 3.9 & 2.2 & 12.2 \\
\hline \multicolumn{11}{|c|}{ Total dissolved solid (TDS) [ppm] } \\
\hline 2001 & 620 & 390 & 290 & 530 & 460 & 250 & 423.3 & 141.7 & 250.0 & 620.0 \\
\hline 2004 & 558 & 318 & 246 & 459 & 274 & 200 & 342.5 & 137.8 & 200.0 & 558.0 \\
\hline 2007 & 590 & 390 & 260 & 490 & 250 & 210 & 365.0 & 151.8 & 210.0 & 590.0 \\
\hline 2010 & 620 & 370 & 240 & 510 & 240 & 220 & 366.7 & 166.3 & 220.0 & 620.0 \\
\hline 2013 & 620 & 340 & 270 & 500 & 280 & 230 & 373.3 & 153.6 & 230.0 & 620.0 \\
\hline
\end{tabular}

The concentration values for nitrate were all below health-based benchmark except few that were close to 10 ppm. The GAMA nitrate concentration (ppm) data showed mean values for nitrate 9.48 for $2012(\mathrm{n}=10) 4.44$ for $2013(n=11) 4.23$ for 2010 ( $n=12), 4.03$ for 2008 and $2009(n=15$ and 13), and 1.57 for $2014(n=4)$.

The Total Dissolved Solids (TDS) values were evaluated for ID4-18, ID4-11, ID4-10, ID1-10, and Wilcox by BWD. We also used the GAMA data conducting statistical review using GAMA model for all other wells in groundwater basin 4-27. While all GAMA values are below the state MCL level (1000 ppm) the studied TDS levels has increased since 2010 for ID1-10, ID 1-12, and ID1-18, and Wilcox. The ID4-10 and ID4-11, and GAMA values showed a drop in TDS values.

The BV groundwater basin was studied extensively in the past years yet none revealed the sources of arsenic and nitrate. However, in our study, we investigate the source of arsenic and nitrate contamination in water through geochemical evolution of groundwater in the BV groundwater basin using hydrogeochemical data, conceptual hydrochemical models and facies. While the physical and chemical parameters of groundwater are important in classifying and assessing water quality [22], the lithology, solution kinetics, and groundwater flow patterns of the aquifer [23] control the hydrochemical facies. To that end, we discuss the hydro-geochemistry facies of the BV groundwater in study area, which we believe is mainly controlled by water-rock interaction.

The primary aquifer in the BV study area is the upper aquifer of a three-tiered, alluvium-filled aquifer system that is underlain by Cretaceous granitic and the triassic or older metasedimentary rocks [24]. The metasedimentary rocks are generally described as biotite schist, gneiss, quartzite, with sparse limestone and dolomite. Fur- 
thermore, the upper aquifer is composed of alluvial, playa, eolian, and fan deposits of Pleistocene to Holocene age and the middle and lower aquifers consist of continental deposits of moderately consolidated gravel, sand, and boulders of Pleistocene age [16]. According to [25] the BV Groundwater aquifer is considered mostly as calcium-sodium-bicarbonate or sodium-mixed anion type waters. Their findings show that bicarbonate accounted for $20 \%$ to $80 \%$ of the total anions, chloride, and sulfate each accounted for $10 \%$ to $60 \%$. In addition, sodium and potassium accounted for $40 \%$ to $100 \%$ of the cations [25]. The $\mathrm{Ca}^{2+}, \mathrm{Mg}^{2+}, \mathrm{SO}_{4}^{2-}$, and $\mathrm{HCO}_{3}^{-}$ may be derived mainly from weathering of carbonate rocks. The latter represent a part of BV lacustrine unit of Palm Spring Formation in the central portion of the valley, where the lacustrine unit was encountered in well logs. The well logs were obtained from the BWD and from published literature after [26].

\subsection{Arsenic}

The most common forms of arsenic in groundwater are their oxy-anions, arsenite $\left(\mathrm{As}^{+3}\right)$ and arsenate $\left(\mathrm{As}^{+5}\right)$. Both cations are capable of adsorbing to various subsurface materials, such as iron oxides and clay particles. Iron oxides are particularly important to arsenate fate and transport as iron oxides, which are abundant in the subsurface and arsenate strongly adsorbs to these surfaces in acidic to neutral waters. Furthermore also suggests arsenic is more soluble in an alkaline and anoxic environment for instance in ID1-10 $(\mathrm{pH}=7.65)$ and for Wilcox $(\mathrm{pH}=7.49)$ (Figure 5(e)). Alkaline condition may produced by the weathering of silicate minerals, which also are to reduce the acidity [27] in BV aquifer. This increase in the $\mathrm{pH}$ to an alkaline condition will cause both arsenite $\left(\mathrm{As}^{+3}\right.$ the predominant species under moderately reducing conditions) and arsenate ( $\mathrm{As}^{+5}$ the predominant species in oxygenated water) to desorb. Hence, they can be expected to be very mobile in an alkaline environment [28]. The pH-Eh condition may also control dissolved arsenic in aqueous environment [29], where under oxidizing conditions or high Eh conditions (Eh $>+100 \mathrm{mV}$ ), iron oxide coatings on soil/sediment particles adsorb and so the concentrations of arsenic in solution usually drops (low). When Eh is low (Eh $<-250 \mathrm{mV}$ ), sulfate in groundwater is reduced; iron, arsenic, and other trace metals may precipitate as sulfide minerals, and the associated aqueous concentrations again are low [29]. According to [29] in the "danger zone" between these extremes $(\sim 0<\mathrm{Eh}<-200 \mathrm{mV})$, the iron oxides and sulfide phases dissolve; any arsenic associated with them is released into the groundwater. The BV groundwater aquifer showed the Eh for the supply well ID1-10 and Wilcox was -71.8 and -61.7 respectively (Figure 5(f)). The positive correlation between arsenic and sulfate suggests that arsenic maybe released in groundwater as the result of the weathering of sulfide minerals (Figure 5(d)). We observed a positive correlation between arsenic and $\mathrm{pH}$ and arsenic with sulfate. There is no correlation between dissolved arsenic and both iron and manganese in the groundwater using GAMA data (Figure 5(g), Figure 5(h)). Note that the 3 points on graph are the mean values of GAMA data for $2007(\mathrm{Fe}[\mathrm{n}=14]$, As $[\mathrm{n}=$ 14]), for 2010 (Fe [n=12], for As [ $n=10]$ ); and for 2013 (Fe $[n=15]$ and As [n= 8]).

Remediation strategies for dissolved arsenic often drive significant shifts in oxidation-reduction potential or Eh. Therefore, arsenic may be either dissolved or precipitated in conjunction with certain treatment technologies. As the release of arsenic requires reducing conditions, a logical remediation suggest that aeration of the arsenic contaminated water might reverse the effect, forcing iron oxide $\left(\mathrm{Fe}(\mathrm{OH})_{3}\right)$ to precipitate, but remove some of dissolved arsenic as it adsorbs to the precipitating oxide surface [30].

\subsection{Nitrate}

The quality of groundwater in the primary aquifer system may be different from that in the shallower or deeper water-bearing zones; shallow groundwater may be more vulnerable to surficial contamination [25]. In terms of nitrate, the results of our study and the synthesis of GAMA data for nitrate from 1980 to 2000 from similar wells throughout the BV groundwater basin as long-term data screening have demonstrated that the higher nitrate concentration in the water of shallow wells occurs in dry years (and dry months, and the lower nitrate concentration in wet years (and wet months September through February). Much work indicates that nitrate concentration values in wells are closely related to the amount of precipitation and its flow in the ground [31] [32]. According to the graph (Figure 6) depicting nitrate data from GAMA and precipitation records from 1980-2000, groundwater pollution in fields with little fertilization and high amount of precipitation is lower due to dilution.

Past research study also suggest nitrate may be introduced to BV aquifer by 4 major recharge systems in BV 1) by stream recharge or the infiltration of runoff (example San Felipe Creek) containing fertilizer and other nutrients runoff from the several creeks and intermittent streams that drain to the valley from the mountains of the 


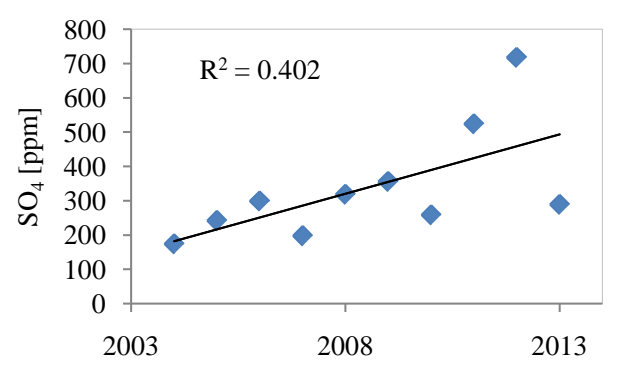

(a)

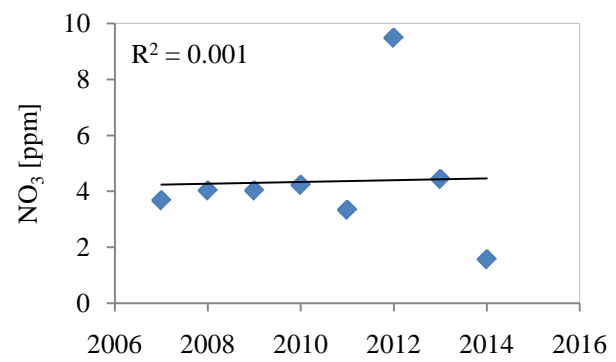

(c)

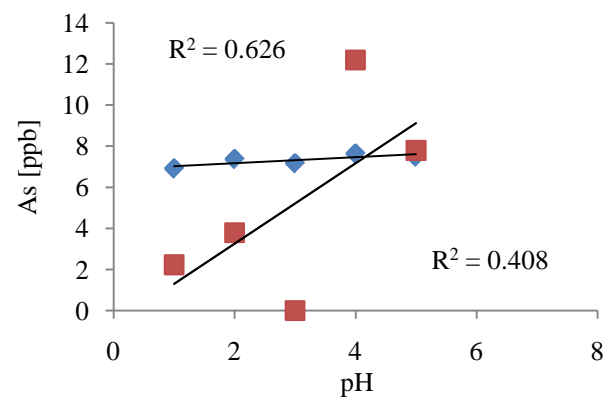

(e)

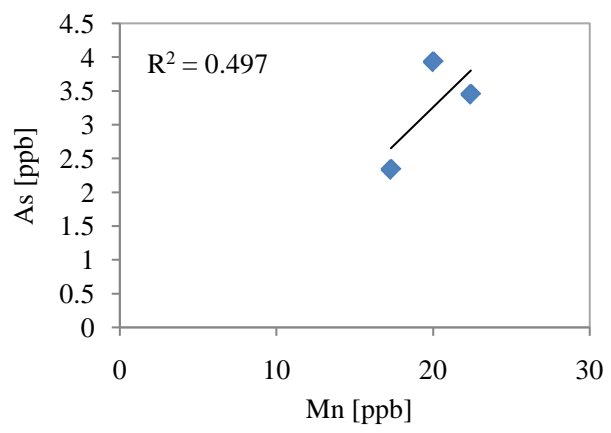

(g)

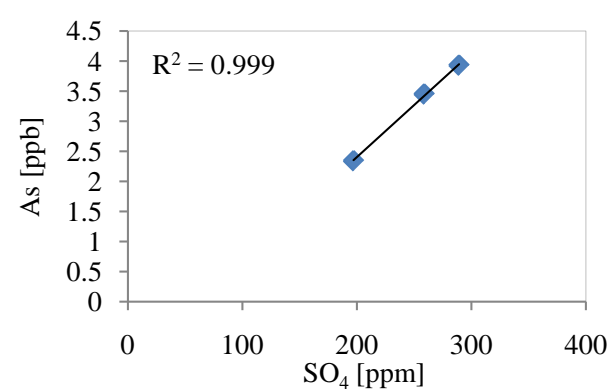

(b)

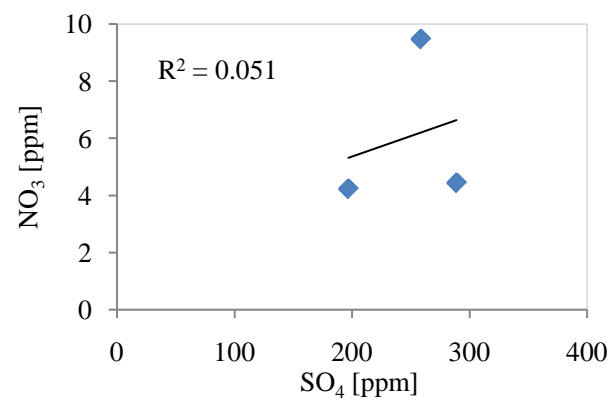

(d)

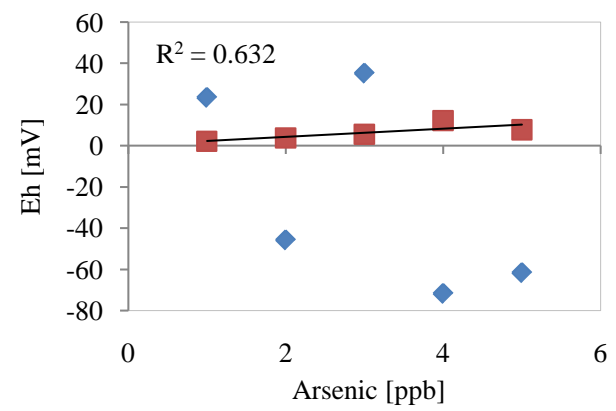

(f)

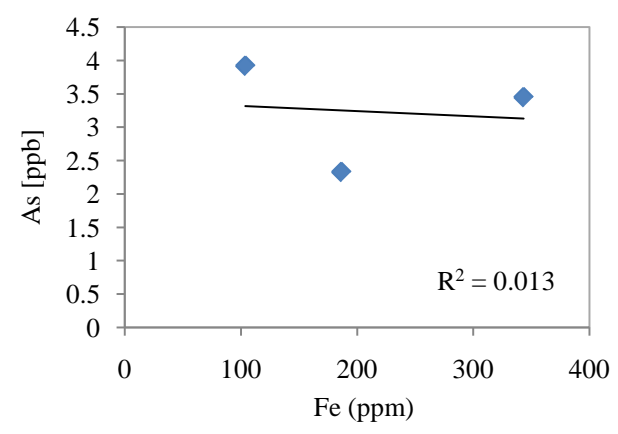

(h)

Figure 5. Clockwise from top-left: (a) Historical record for sulfate mean concentration (n = 152) from 2004 to 2014 based on GAMA ( $\left.\mathrm{R}^{2}=0.40\right)$; (b) Correlation of arsenic and sulfate concentration values from mean data record of $2007\left(\mathrm{SO}_{4}[\mathrm{n}=\right.$ 25], for As [n=14]), $2010\left(\mathrm{SO}_{4}[\mathrm{n}=16]\right.$, As [n=10]); and for 2013 (for $\mathrm{SO}_{4}[\mathrm{n}=20]$ and for As [n = 8]); (c) Historical record for nitrate concentration from 2007 to 2014 based on mean GAMA data $(\mathrm{n}=98)$. The graph shows fluctuation pattern for nitrate; (d) There is a weak correlation between nitrate and sulfate. The mean values of $\mathrm{NO}_{3}$ and $\mathrm{SO}_{4}$ were used for 3 different years $\left(\mathrm{SO}_{4}[\mathrm{n}=25], \mathrm{NO}_{3}[\mathrm{n}=18]\right)$, for $2010\left(\mathrm{SO}_{4}[\mathrm{n}=16], \mathrm{NO}_{3}[\mathrm{n}=12]\right)$; and for 2013 (for $\mathrm{SO}_{4}[\mathrm{n}=20]$ and for $\left.\mathrm{NO}_{3}[\mathrm{n}=11]\right)$; (e) Correlation of As with $\mathrm{pH}(\mathrm{n}=6)$; ( $\mathrm{f}$ ) Correlation of As with Eh $(\mathrm{n}=6)$; $(\mathrm{g})$ Correlation of Mn versus As using mean GAMA data for 2007 (Mn [ $=14]$, As [ $=14]$ ), 2010 (Mn [n = 10], As [n = 10]); and for 2013 (for Mn [n = 9] and for As [n = 8]); (h) Correlation between Fe and As using mean GAMA data for 2007 (Fe [n = 14], As [n = 14]), for 2010 (Fe [n=12], for As [n=10]); and for 2013 (Fe [n=15] and As [n= 8]). 


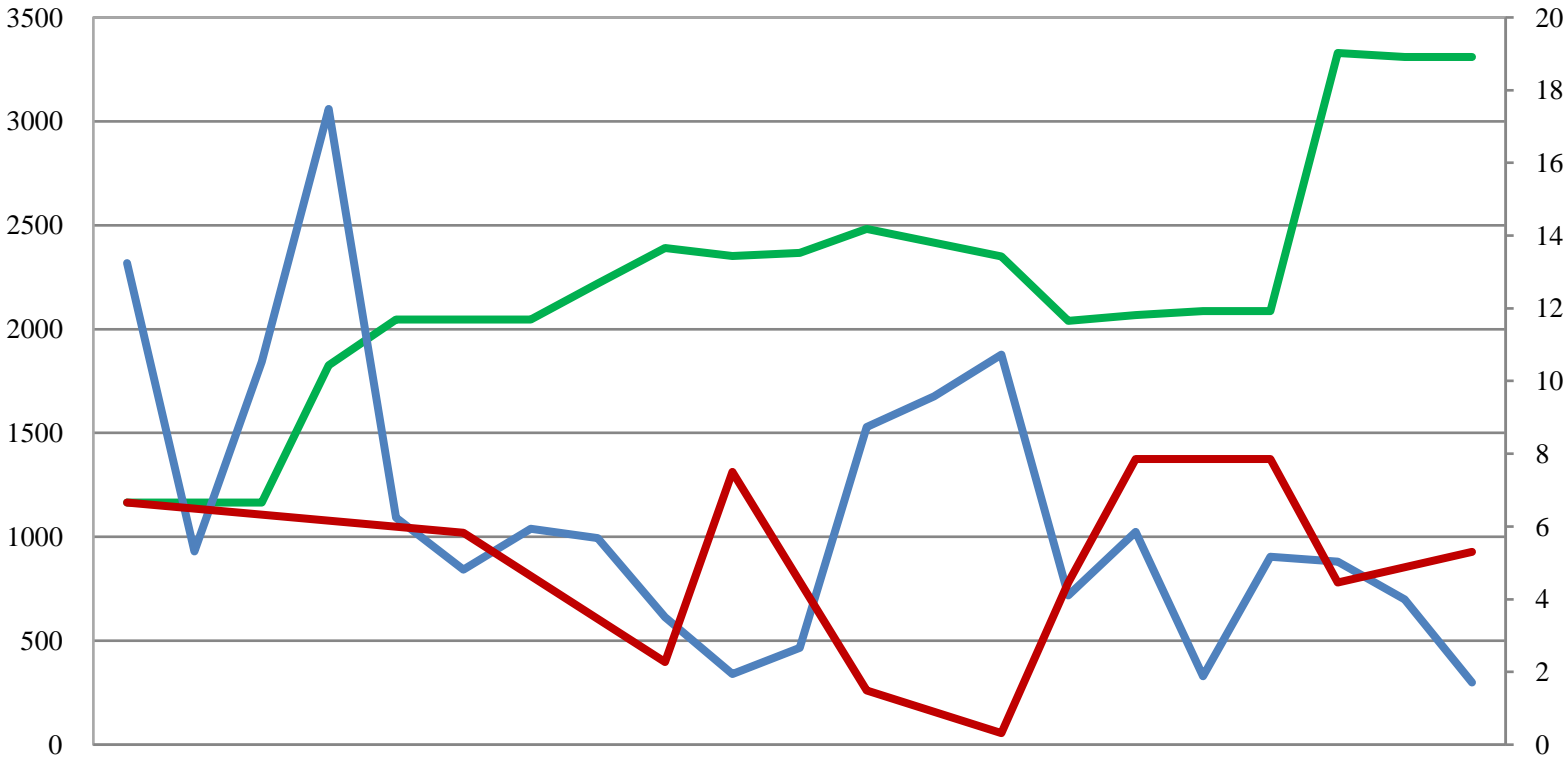

198019811982198319841985198619871988198919901991199219931994199519961997199819992000

— Net Production [14 \% Return acre-feet] — Percipitation [in] _ Nitrate [ppm]

Figure 6. Comparing the precipitation, nitrate concentration from different wells and return flow values from 1980 to 2000. The return flow is the portion of the water pumped from the BV aquifer for irrigation of citrus groves and for golf course grass, which returns to the aquifer via seepage through the vadose zone. There was no data recorded for nitrate from 1981 to 1985.

surrounding watershed in wet season. The stream runoff was estimated by Netto, 2001, approximately 600 acre-feet to approximately 26,000 acre-feet annually and average 3860 acre-feet per year during the period 1945 through 2000 [2]; 2) by bedrock recharge, which occurs as subsurface seepage into the aquifer from the fractured crystalline basement rocks surrounding the basin, this may accelerate the nitrate migration downward due to gravity flow; 3) the underflow from adjacent basins, where groundwater flow through saturated alluvial sediments containing high level of nitrate from adjacent basins or through alluvial filled channels entering BV aquifer. This may cause mixing of an aquifer with low nitrate concentration with adjacent aquifer with the high nitrate concentration. According to [17] the underflow along San Felipe Creek was estimated to be approximately 32 acre-feet per year (af/yr) [17]; 4) irrigation return flow or artificial recharge; it is that portion of the water pumped from the BV aquifer for irrigation of citrus groves and for golf course grass, which returns to the aquifer via seepage through the vadose zone. An estimated irrigation return flow, using the chloride mass balance technique was conducted for 2 Mojave Desert sites [33], was calculated for the citrus grove of 22 percent of the applied irrigation rate or approximately $888 \mathrm{~m}^{3} / \mathrm{y}(0.72 \mathrm{af} / \mathrm{yr} / \mathrm{acre})$ and for the golf course, the return rate on the golf course of 14 percent of the applied irrigation rate, or approximately $1036 \mathrm{~m}^{3} / \mathrm{y}(0.84 \mathrm{af} / \mathrm{yr} / \mathrm{acre})$.

All other irrigation in BV was assumed to generate 14 percent return flow [2]. We anticipate that groundwater flow conditions can vary from year to year, depending on factors such as the amount of precipitation, the amount of regional pumping from the aquifers, seasonality changes in hydraulic gradient, and changes in recharge and discharge and irrigation pattern [34]. Therefore, it is not surprising that nitrate levels may be fluctuating by local and regional dynamics of groundwater flow affecting variation in nitrate concentration throughout the year or from year to year (Figure 6). The graph shows higher precipitation record results in lower nitrate concentration between 1980 and 2000 while the return flow of irrigation values gradually increasing through the same time period.

Beside natural sources, human activities on land surface and in the subsurface can affect groundwater quality. Land-use data commonly are used to identify potential effects of such activity because each type of land use typically is associated with specific activities and certain changes in water quality. Land use in the study unit is 
92 percent natural, 2.7 percent agricultural, and 5.7 percent urban, according to classifications from USGS National Land Cover Data [35]. Recreation has become the second most intensive use of groundwater in BV. The primary use of water for recreational activities in BV is for irrigation of the several golf courses in BV. The gross irrigation applied across all golf courses is estimated to be approximately 6 feet per year [2]. Wells ID4-2 and ID4-3 have been taken out of production by BWD and no longer used due to high nitrate concentration recorded above MCL. According to topographic map, these wells are located approximately on the east side of De Anza, Club Circle, and BSPCSD Golf Course (Figure 2). Moreover, treatment as well as reducing the return flow of Golf Course irrigation and fertilizer application may also contribute to lower contamination of nitrate in BV groundwater aquifer.

\section{Conclusion}

The groundwater basin system of BV is comprised of three hydraulically distinct aquifers that will likely provide sufficient supply if properly managed. However, nitrate and arsenic contamination in groundwater may be a concern for the study area. The results of this preliminarily study indicate that nitrate concentration is not exceeding regulatory limits (MCL $=45 \mathrm{ppm}$ ) but shows some sign of increase of arsenic in only one well (around and/or slightly above $10 \mathrm{ppb}$ ). This may not be ruled out as an imminent threat but we suggest that further monitoring of the nitrate and arsenic levels (e.g. wet season water sampling) is necessary to evaluate the temporal evolution and distribution of nitrate and arsenic concentrations within the aquifers underlying the region. Under these circumstances, future studies using nitrogen, oxygen, and carbon isotopes are also required to better assess the migration pattern of the specific sources and contributions of nitrate to the BV groundwater aquifer.

\section{Acknowledgements}

The authors thank Dr. Tim Ross at Department of Water Resources. This research study would not have been possible without his assistance. We thank also Mr. Jerry Rolwing, General Manager at Borrego Water District for allowing the groundwater well sampling and access to wells, and also working with us tirelessly on sampling day, providing us valuable information for this study regarding groundwater use and information about wells in Borrego Valley area.

\section{References}

[1] Water Education Foundation (2006) Where Does My Water Come from? Sacramento, Calif., Water Education Foundation. http://www.watered.org/watersources/default.asp

[2] Netto, S.P. (2001) Water Resources of Borrego Valley San Diego County, California. Thesis, Master of Science in Geological Sciences, 159 p.

[3] Mathany, T.M., Wright, M.T., Beuttel, B.S. and Belitz, K. (2012) Groundwater-Quality Data in the Borrego Valley, Central Desert, and Low-Use Basins of the Mojave and Sonoran Deserts Study Unit, 2008-2010—Results from the California GAMA Program. U.S. Geological Survey Data Series 659, 100 p.

[4] Welch, A.H., Lico, M.L.S. and Hughes, J.L. (1988) Arsenic in Ground Water of the Western United States. Groundwater, 26, 333-347. http://dx.doi.org/10.1111/j.1745-6584.1988.tb00397.x

[5] Fetter, C.W. (2008) Contaminant Hydrogeology. 2nd Edition, Waveland Press Inc., Long Grove, 500 p.

[6] Azaza, F.H., Ketata, M., Bouhlila, R., Gueddari, M. and Riberio, L. (2010) Hydrogeochemical Characteristics and Assessment of Drinking Water Quality in Zeuss-Koutine Aquifer, Southeastern Tunisia. Environmental Monitoring and Assessment, 174, 283-298. http://dx.doi.org/10.1007/s10661-010-1457-9

[7] Carrillo-Rivera, J.J., Varsányi, I., Kovács, L.Ó. and Cardona, A. (2007) Tracing Groundwater Flow Systems with Hydrogeochemistry in Contrasting Geological Environments. Water, Air, \& Soil Pollution, 184, 77-103. http://dx.doi.org/10.1007/s11270-007-9400-6

[8] Spalding, R.F. and Exner, M.E. (1993) Occurrence of Nitrate in Groundwater-A Review. Journal of Environmental Quality, 22, 392-402. http://dx.doi.org/10.2134/jeq1993.00472425002200030002x

[9] Mandal, B.K., Chowdhury, T.R., Samanta, G., Mukherjee, D.P., Chanda, C.R., Saha, K.C. and Chakraborti, D. (1996) Impact of Safe Water for Drinking and Cooking on Five Arsenic-Affected Families for 2 Years in West Bengal, India. Science of the Total Environment, 218, 185-201. http://dx.doi.org/10.1016/S0048-9697(98)00220-4

[10] Ravenscroft, P., McArthur, J.M. and Hoque, V. (2001) Geochemical and Palaeohydrological Controls on Pollution of Groundwater by Arsenic. In: Chappell, W.R., Abernathy, C.O. and Calderon, R., Eds., Arsenic Exposure and Health 
Effects IV, Elsevier Science Ltd., Oxford, 53-77.

[11] Schreiber, M.E., Gotkowitz, M.B., Simo, J.A. and Freiberg, O.G. (2003) Mechanisms of Arsenic Release to Ground Water from Naturally Occurring Sources, Eastern Wisconsin. In: Welch, A.H. and Stollenwerk, K.G., Eds., Arsenic in Ground Water, Kluwer Academic Publishers, Dordrecht, 259-280. http://dx.doi.org/10.1007/0-306-47956-7 9

[12] Acharyya, S.K., Lahiri, S., Raymahashay, B.C. and Bhowmik, A. (2000) Arsenic Toxicity of Groundwater in Parts of the Bengal Basin, in India and Bangladesh: Role of Quaternary Stratigraphy and Holocene Sea-Level Fluctuation. Environmental Geology, 39, 1127-1137. http://dx.doi.org/10.1007/s002540000107

[13] McArthur, J.M., Banerjee, D.M., Hudson-Edwards, K.A., Mishra, R., Purohit, R., Ravenscroft, P., Cronin, A., Howarth, R.J., Chatterjee, A., Talukder, T., Lowry, D., Houghton, S. and Chadha, D.K. (2004) Natural Organic Matter in Sedimentary Basins and Its Relation to Arsenic in Anoxic Ground Water: The Example of West Bengal and Its Worldwide Implications. Applied Geochemistry, 19, 1255-1293. http://dx.doi.org/10.1016/j.apgeochem.2004.02.001

[14] Rezaie-Boroon, M.H., Gnandi, K. and Folly, K.T. (2011) Presence and Distribution of Toxic Trace Elements in Water and Sediments of the Southern Togo Rivers Watershed, West Africa. PSP Environmental Bulitin, 20, 1853-1865.

[15] Mills, W.R. (2009) Integrated Water Resources Management Plan. Final Report, 128 p.

[16] California Department of Water Resources DWR (2004) California’s Groundwater Individual Basin Descriptions. California Department of Water Resources Bulletin 118, Lucerne Valley.

http://www.water.ca.gov/pubs/groundwater/bulletin_118/basindescriptions/7-19.pdf

[17] Moyle Jr., W.R. (1982) Water Resources of Borrego Valley and Vicinity, California; Phase 1-Definition of Geologic and Hydrologic Characteristics of Basin. U.S. Geological Survey Open-File Report 82-855, 39 p.

[18] Mitten, H.T., Lines, G.C., Berenbrock, C. and Durbin, T.J. (1988) Water Resources of Borrego Valley and Vicinity, San Diego County, California: Phase 2-Development of a Ground-Water Flow Model. U.S. Geological Survey WaterResources Investigations Report 87-4199, 27 p.

[19] Smedley, P.L., Nicolli, H.B., Macdonald, D.M.J., Barros, A.J. and Tullio, J.O. (2002) Hydrogeochemistry of Arsenic and Other Inorganic Constituents in Groundwater from La Pampa, Argentina. Applied Geochemistry, 17, 259-284. http://dx.doi.org/10.1016/S0883-2927(01)00082-8

[20] Wilde, F.D. (2004) Cleaning of Equipment for Water Sampling (Ver. 2.0). U.S. Geological Survey Techniques of Water-Resources Investigations, Book 9, Chap. A3. http://pubs.water.usgs.gov/twri9A3/

[21] Wilde, F.D., Radtke, D.B., Gibs, J. and Iwatsubo, R.T. (1999) Collection of Water Samples (Ver. 2.0). U.S. Geological Survey Techniques of Water-Resources Investigations, Book 9, Chap A4. http://pubs.water.usgs.gov/twri9A4/

[22] Jahin, H.S. and Gaber, S.E. (2011) Study of Groundwater Quality in El-Kharga Oasis, Western Desert, Egypt. Asian Journal of Water, Environment and Pollution, 8, 1-7.

[23] Raju, N.J., Ram, P. and Dey, S. (2009) Groundwater Quality in the Lower Varuna River Basin, Varanasi District, Uttar Pradesh. Journal of the Geological Society of India, 73, 178-192. http://dx.doi.org/10.1007/s12594-009-0074-0

[24] Dibblee Jr., T.W. (1984) Stratigraphy and Tectonics of the San Felipe Hills, Borrego Badlands, Superstition Hills, and vicinity. In: Rigsby, C.A., Ed., The Imperial Basin-Tectonics, Sedimentation, and Thermal Aspects, Pacific Section SEPM, Los Angeles, 31-34.

[25] Parsons, M.C., Hancock, T.C., Kulongoski, J.T. and Belitz, K. (2014) Status of Groundwater Quality in the Borrego Valley, Central Desert, and Low-Use Basins of the Mojave and Sonoran Deserts Study Unit, 2008-2010: California GAMA Priority Basin Project. USGS Scientific Investigations Report: 2014-5001, 88 p.

[26] Threet, R.L. (1972) Hydrogeology of Southern Borrego Valley. Prepared 13 April 1972 for: George J. Kuhrts III, Borrego Springs, California.

[27] Pazand, K. and Fereidoni Sarvestani, J. (2013) Hydrogeochemical Investigation in an Arid Region of Iran (Tabas, Central Iran). Environmental Earth Sciences, 70, 743-752. http://dx.doi.org/10.1007/s12665-012-2162-5

[28] Henkel, S. and Polette, D. (1999) Arsenic in Ground Water of the Willamette Basin, Oregon. U.S. Geological Survey Water-Resources Investigations Report 98-4205, 27 p.

[29] Stein, C.L., Brandon, W.C. and McTigue, D.F. (2005) Arsenic Behavior under Sulfate-Reducing Conditions: Beware of the "Danger Zone”. EPA Science Forum 2005: Collaborative Science for Environmental Solutions, 16-18 May 2005, Washington DC.

[30] Andrews, J.E., Brimblrcombe, P., Jickells, T.D., Liss, P.S. and Reid, B.J. (2003) An Introduction to Environmental Chemistry. 2nd Edition, Wiley-Blackwell, Hoboken, 296 p.

[31] Gopal, B.K. (1990) Investigation of Nitrate Contamination in Shallow Ground Waters near Wood Ward, Oklahoma. Ground Water Quality and Agricultural Practices. Lewis Publishers, Boca Raton, 247-264.

[32] Rutkoviene, V., Kusta, A. and Èesoniene, L. (2005) Environmental Impact on Nitrate Levels in the Water of Shallow Wells. Polish Journal of Environmental Studies, 14, 631-637. 
[33] Prudic, D.E. (1994) Estimates of Percolation Rates and Ages of Water in Unsaturated Sediments at Two Mojave Desert sites, California-Nevada. U.S. Geological Survey Water Resources Investigations Report 94-4160, 19 p.

[34] Murgulet, D. and Tick, G.R. (2009) Assessing the Extent and Sources of Nitrate Contamination in the Aquifer System of Southern Baldwin County, Alabama. Environmental Geology, 58, 1051-1065. http://dx.doi.org/10.1007/s00254-008-1585-5

[35] Vogelmann, J.E., Howard, S.M., Yang, L., Larson, C.R., Wylie, B.K. and Van Driel, N. (2001) Completion of the 1990s National Land Cover Data Set for the Coterminous United States from Landsat Thematic Mapper Data and Ancillary Data Sources. Photogrammetric Engineering \& Remote Sensing, 61, 650-662. 
Scientific Research Publishing (SCIRP) is one of the largest Open Access journal publishers. It is currently publishing more than 200 open access, online, peer-reviewed journals covering a wide range of academic disciplines. SCIRP serves the worldwide academic communities and contributes to the progress and application of science with its publication.

Other selected journals from SCIRP are listed as below. Submit your manuscript to us via either submit@scirp.org or Online Submission Portal.
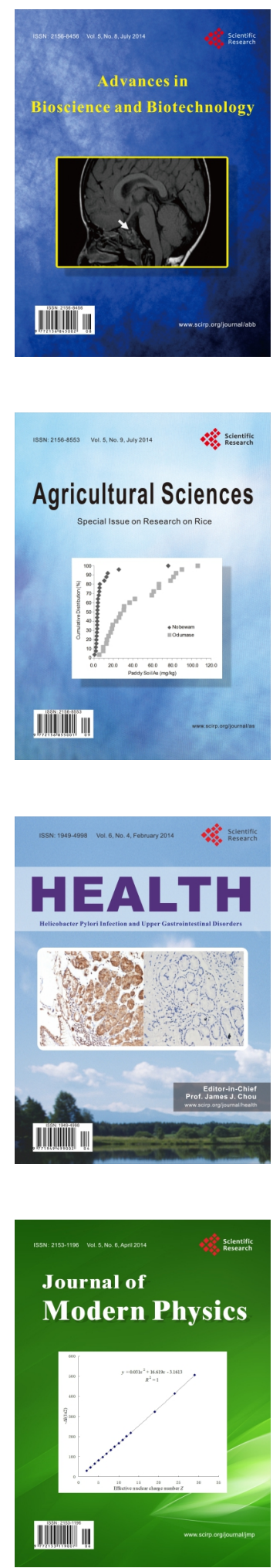
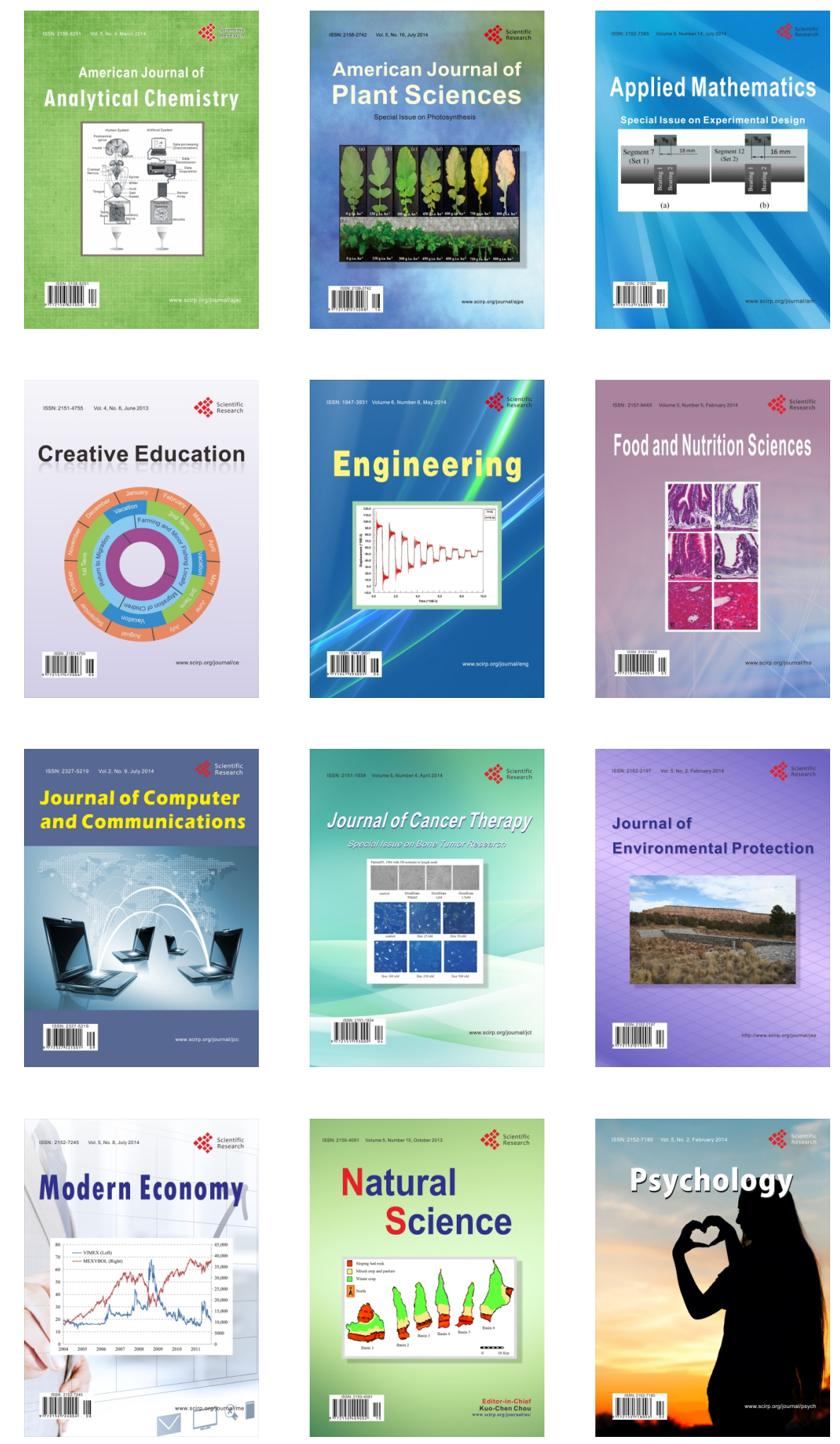